During an evening session, to which a much wider audience had been invited, Dr. D. A. Spencer gave an account of present-day colour photography, illustrated by a cartoon film. This lecture was very much appreciated, and the large attendance showed the widespread interest created. The whole of the conference was very well attended, and the discussion was often very lively, demonstrating the need of informal meetings of this type, in which the aim is partly to bring forward new pieces of research, but partly also to relate already published information of the type not easily accessible to the physicist in industry. The hospitality and general arrangements pro- vided by the Physics Department of the University of Manchester were very much appreciated by all participants. IV. F. BERG.

NATCRE, 140, 997 (1937).

- Gurney and Mott, Proc. Roy. Soc., A, 164, 151 (1938).

'Wagner, Z. phys. Chem., B, 21, 25 (1933).

- Papers by Garner, Wischin and IIott, Proc. Roy. Soc. In the Press.

- Sheppard, Phot. J., 65, 380 (1925).

- Fvans and Webb, J. Opt. Soc. Amer., 28, 431 (1938).

? Webb, Phot. J., 76, 78 (1936).

- Strock, Skrifter utgitt av det Yorsk Videnskaps-Akademi i Oslo, (I) Inat.-Naturv. Klasse, No. 10 (1933).

- Berg, Transi Farad. Soc., 35, 145 (1939).

is ibid., footnote, p. 458 .

${ }^{10}$ Berg and Mendelssohn, Proc. Roy. Soc., A, 163, 163 (1933).

$"$ Evans and Hirschlaff, J. Opt. Soc. Amer., 29, 104 (1939).

${ }^{13}$ Juch of the matter of this lecture may be found in Ross, "The Physies of the Ieveloped Photographic Image" (New York, 1924). " Hopkinson, Phot. J.. 76, 323 (1936).

\title{
OBITUARIES
}

\section{Prof. J. Mellanby}

$\mathrm{T}$ HE death of Prof. John Nellanby on July 15 at the age of sixty years takes from us not only a great physiologist but also a notably genial and kindly personality. He will long be remembered by his colleagues and his students for his penetrating wisdom as well as for his ever-ready willingness to help.

Mellanby went up to Emmanuel College, Cambridge, in 1896 and took Part II of the Science Tripos in 1900 , having been an early student under Gowland Hopkins, who had just begun to teach biochemistry at Cambridge at that time. From Cambridge he went to the research laboratory newly founded by Burroughs and Welleome at Brockwell Hall, and worked there chiefly on the properties of serum proteins and their relation to antitoxins. He left there to complete his clinical course at Manchester and took his Mr.D. at Cambridge in 1907 and returned to the Cambridge laboratory as George Henry Lewes student. Ho was still engaged on protein solutions, and in particular on the phenomenon of clotting in blood and milk.

In 1909 Mellanby left Cambridge to take charge of the Physiological Department of St. Thomas's Hospital and began to use the measurement of the clottingtime of milk as a sensitive method for determining the quantity of active trypsin in pancreatic juice, and thus to work out the details of the formation of trypsin from trypsinogen. From the properties of the juice he went on to elucidate the mechanism of its secretion, and it is perhaps his work on this and on the purification of secretin which, together with his earlier investigation of clotting, form his best-known contributions to knowledge.

Mellanby became a fellow of the Royal Society in 1929 and at the time of his death was a member of its Council and of the Medical Research Council. But his purely physiological work was only one part of his activity. What was always in his mind was the encouragement of research from the clinical side, and he was at all times anxious to help, both by advice and in practice, in any problem that might be brought to him. Ho felt that problems in medicine were problems in physiology and that both were only to be solved by experiment. Such problems arose in the most varied fields and were responsible. for example, for his work with Anwyl-Davies on the anti-coagulant action of arsenobenzol and the making of colloidal gold solution, and with C. R. Box on glycosuria.

In 1937 Mellanby became professor of physiology at Oxford and continued there the work on visceral movement to the study of which he had been led by his work on the effects of secretin. Ho finished an investigation of the changes in size of the spleen shortly before his death. In Oxford, as in London, he was in close touch with his elinical colleagues and his influence on the future of the Nuffield Foundation would have been of immense value. As a researcher he was outstandingly original and versatile, and it is safo to say that time will enlance his reputation in the fields which he made his own.

\section{J. WOOLLEY.}

\section{Dr. M. A. Usov}

The death occurred on July 26 of one of the most eminent Soviet geologists, Mikhail Antonovich Usov, member of the Academy of Sciences of the U.S.S.R., and director of the All-Union Institute of Coordinated Geological Research.

Usov's work was mainly concerned with questions of tectonics and petrology. Ho elaborated a new method for the study of the tectonics of coal deposits, making use of the vast materials available from underground workings, to which geologists had until then paid little attention. An analysis of the breaks he had observed induced him to make an exhaustive classification of the forms of volcanic dislocations. This resulted in the appearance of several works on the tectonics both of individual mines and of the entire Kuznetsk Basin. In these works he revealed 